\title{
Beyond Bosnia: Contextualizing the Politics of Southeastern Europe ${ }^{1}$
}

\author{
Charles King, Georgetown University
}

A rms merchants and pop historians may well have been the chief beneficiaries of the Balkan wars of the 1990s. Through weapons sales to the Yugoslav successor states, arms merchants have ensured that the region's military and political elites have been able to "cleanse" territories once populated by a plethora of ethnic and religious communities, and to perpetrate war crimes whose extent and viciousness have not been seen in Europe for five decades. Through their best-selling books, op-ed articles, and television appearances, pop historians have told us why it could not have been otherwise. The image of the Balkans as an area of timeless ethnic conflict, where ties of blood and land inevitably trump concepts of citizenship and democracy, has become a commonplace in commentaries on the region. In a new edition of its famous 1913 report on the Balkan wars, the Carnegie Commission drew an explicit parallel between the atrocities of Bulgarian, Turkish, and Serbian troops in the early part of this century and the heinous war crimes committed in the 1990s. Western policymakers, warned George Kennan in his introduction to the new edition, would do well to consider those "deeper traits of character inherited ... from a distant tribal past" which would inevitably frustrate the ability of the Balkan peoples to live peacefully with one another (Carnegie Endowment 1993, 11).

Political science courses on the Balkans are an uncommon commodity. The study of the region has traditionally been left to historians, and more recently, to journalists, whose conclusions have normally echoed those of the Carnegie report. In the rare instances in which the Balkans are covered in comparative politics surveys of Eastern Europe, the region usually receives far less space on the syllabus than the more developed "northern tier" states of Poland, the Czech Republic, Hungary, and Slovakia. However, there are compelling reasons for bringing the study of Europe's southeast into the mainstream of comparative politics and for making the region a focus of undergraduate and graduate courses. In the first place, the region provides many cases of issues of pressing interest to comparativists: identity politics, nationalism, mass mobilization, state-building, and regime change, among many others. Moreover, the difficult transitions experienced in the Balkans are clearly the rule rather than the exception in Eastern Europe. Indeed, the southeast is a far more representative example of post-communism than the northern tier states. The four "Visegrad" countries, in which foreign interest and investment have been highest, are actually rather unreliable indicators of the key challenges confronting post-communist states; with the exception of Slovakia, none of these countries faces the major problems bedeviling states in most other parts of the former communist world. From Croatia to Kyrgyzstan, issues of national borders, ethnic minorities, low foreign investment, residual authoritarianism, widespread corruption, and civil disorder have characterized the transition period. If we want to know what post-communism is really like, Southeastern Europe is the place to look.

Exploring these issues and attempting to place the study of the region within the context of comparative politics were the core aims of a course on "Communism, Nationalism and Democracy in the Balkans," an undergraduate lecture and discussion class which drew students from Georgetown's School of Foreign Service and the Department of Government. In developing a political science course on the Balkans, I was most interested to have students reflect critically on the perceptions of Southeastern Europe that they had encountered in the media and to question the distinctions between political behavior in this region and in other parts of Europe. In the end, I found the course a marvelous vehicle for exploring a variety of questions of concern to political scientists in general: How do political traditions condition the choice of institutions during a period of regime change? What role do ethnic affiliations play when other forms of political association break down? Are federal states inherently unstable? What is "ethnic conflict," and what role can outside powers play in helping bring it to an end? By beginning with these big questions, the course encouraged students to think comparatively about recent political developments in the Balkans, rather than assuming that what has happened in the region over the last seven years must be the inevitable result of a distinctly Balkan political culture.

\section{The West and the Rest}

Early in the course, we spent a considerable amount of time studying political, historical, and topographical maps of the region. We also surveyed the cultural, linguistic, and political heritage of each of the states of Southeastern Europe, from independence through the collapse of communism. Since most students came to the course with very little knowledge of the complex ethnic geography, linguistic groups, and cultural traditions of the area, some basic identification was in order. The students were full of questions about places, names, and terms they had seen in the newspapers, but which had never been adequately explained: How do you pronounce "Karadzic" or "Hoxha"? Where did the Albanians come from? How did the Muslims get so far north? Where is Transylvania or Bessarabia or the Sandzak? On the first day of classes, I also distributed my own fairly detailed guide to the pronunciation of East European languages, so that some of the place-names and per- 
sonages would not seem so formidable.

For the purposes of this course, I defined "the Balkans" as Romania, Bulgaria, Albania, and the successor states of the Socialist Federative Republic of Yugoslavia (Slovenia, Croatia, Bosnia-Herzegovina, Macedonia, and the Federal Republic of Yugoslavia). Such a designation is, of course, controversial. Greece and Turkey may count geographically as part of the Balkans, but both are loath to be lumped in the same political category with Albania-or, for that matter, with each other. Romanians are quick to underscore the fact that their Latin heritage sets them apart from their mainly Slavic neighbors. Croats and Slovenes, with their legacy of rule from Budapest and Vienna, are equally disinclined to feel themselves part of the same region as the formerly Ottoman-controlled Serbs and Macedonians. Critiquing the notion of "the Balkans" as a coherent geographical entity provided a useful introduction both to the cultural complexity of Europe's southeast, as well as to the uses of labels such as "east" and "west" in discourses on European history and politics (subjects taken up in Wolff 1994 and Todorova 1997). Moreover, with maps in hand, students were able to reflect on the ways in which our own "symbolic geography" (Bakic-Hayden and Hayden 1992) might condition our perceptions of culture and politics in Southeastern Europe. For example, some were surprised to see that Sarajevo is as far west as Stockholm, that Zagreb is considerably west of Budapest and Warsaw, and that the Albanian coast is easily visible to holiday makers on the island of Corfu.

\section{Teaching Materials}

Despite the plethora of books and articles on the former Yugoslavia, finding appropriate teaching materials for a political science course on the Balkans can be problematic. The study of the Balkans has been doubly disadvantaged within political science. The study of Eastern Europe in general has long been considered one of the most methodolog- ically backward subfields within comparative politics. And within that subfield, the Balkans have been overshadowed by research on Russia and the "northern tier." Finding good general, comparative texts can therefore be a serious concern. Instructors must often rely on journalistic and historical treatments of the region, studies which usually tend to assume-rather than demonstratethat the roots of national identity run deeper in the southeast than anywhere else.

For this course, I supplemented material from five main texts (Jelavich 1983; West [1940] 1993; Verdery 1991; Woodward 1995a; Rieff 1995) with readings from political science and area studies journals, travelers' accounts, novels, journalists' reports, and occasional video presentations. Volume Two of Barbara Jelavich's survey of the modern Balkans is still the best introduction to the region. Although the reading can be tough going, especially for those whose command of European history is incomplete, students were generally grateful to have a solid reference book that put the region's elaborate dramatis personae in some historical context.

One can say without too much exaggeration that Rebecca West's Black Lamb, Grey Falcon is one of the half-dozen best travel books written on any region. Students initially looked askance when presented with its 1,200 pages, but by the end of the course, there was general agreement that West provided an insightful, if controversial, portrait of Yugoslavia in the interwar years. An article by Hall (1996) highlighted the enduring relevance of West's work by noting the influence of Black Lamb on the new generation of Balkan correspondents in the 1990 s.

Katherine Verdery's anthropological interpretation of Romanian nationalism served as the basic text on the communist period, supplemented again by journal articles and the relevant sections from Jelavich. Since Verdery deals with the uses of nationalism by communist intellectuals and political leaders, and her book provided an excellent introduction to the politics of national identity after the demise of the communist system. Susan Woodward's political economy of the Yugoslav federation and its disintegration received universal approval from the students, as did David Rieff's more polemical treatment of the role of international organizations in the Yugoslav wars.

These texts were supplemented by occasional videos on topics that we could not cover adequately during the lectures and class discussions. Emir Kusturica's Time of the Gypsies (1990), which won the best director award at Cannes, is a moving, magical-realist saga of a Romani (Gypsy) boy's coming of age in Bosnia. The Oak (1992), directed by the acclaimed Romanian filmmaker Lucian Pintilie, offers a macabre look at life in the waning Ceausescu years. The six-part documentary series Yugoslavia: Death of a Nation (1995), which accompanies a readable but sometimes inaccurate paperback text on Yugoslavia's demise by Silber and Little (1995), is a monumental work of contemporary "video history" (but has both the advantages and shortcomings that such a medium entails). During the last part of the course, when we focused on the end of $\mathrm{Yu}$ goslav federalism, the video series gave some coherence to the often confusing array of actors and events; moreover, since the series is not without its problems-including at times inaccurate translations and a tendency to present a particular interpretation of Yugoslavia's demise as established historical fact-it provided an opportunity for further discussion of the media's role in conditioning Western perceptions of and responses to the Yugoslav crisis.

\section{Political Science and Historical Sensitivity}

I organized the course in three sections, each of which centered on a number of key interpretive questions which asked the students to place the experience of the Balkans in a wider intellectual context. These questions then formed the basis for lectures and for questions on the final essay exam. The goal was to make sure that students came away from the course with both an appreciation for the broad conceptual questions raised by recent events in the Balkans, as well as a feel for the 
major historical developments in the region over the last century.

The first section surveyed the history of the Balkan peoples within the Ottoman and Habsburg empires, the establishment of national states in the late nineteenth and early twentieth centuries, and the turbulent politics of nation- and statebuilding between the two world wars. Questions addressed in this section included:

- What political traditions were "inherited" from the Ottoman period? How do we know?

- How did political elites cope with the problem of integrating ethnically and religiously diverse populations between the two World Wars?

- Why was Romania the only Balkan country to develop a strong, indigenous fascist movement in the interwar years?

- How did the bases of political legitimation differ for communist parties in Romania and Bulgaria from those in Yugoslavia and Albania?

In addition to readings from Jelavich, selections from general surveys and more specialized monographs by Wolff (1974), Banac (1984), Chirot (1989), and Rothschild (1974) provided helpful background to the lectures.

The second section focused on the experience of communism and postcommunism. The emphasis here was on comparison-comparing the experience of Balkan states with each other, as well as with neighboring states in Central Europe and the Mediterranean/Black Sea zone, especially Greece and Turkey. Study questions in this section included:

- Was there such a thing as "Balkan Communism"? If so, what were its main components?

- What uses did nationalism serve for Balkan political elites? How and why did it differ from nationalism in other European states?

- What kinds of parties have emerged since the collapse of communism? How do the party systems compare with those in other states in transition?

- What sorts of institutional struc- tures exist for dealing with ethnic heterogeneity?

Several specialized studies were placed on reserve in the university library, and students made considerable use of these in preparing the review essays and term papers required for the course. Hall (1994) and Vickers (1995) are the best recent treatments of Albania, as are Poulton (1995) and Danforth (1994) for Macedonia. Bringa (1995) and Friedman (1996) give, respectively, anthropological and historical treatments of Bosnian Muslim identity, while Deletant (1995) and Gallagher (1995) concentrate on the interplay of nationalism and political repression in communist and post-communist Romania. Since the course, two other country studies by Judah (1997) and Tanner (1997) have appeared, but while accessible, both works are "general reader" accounts of Serbia and Croatia rather than works of scholarship.

In the final section, we turned our attention to political developments in the region's two largest states, Romania and the former Yugoslavia, and examined, among other issues, the sources of ethnic and political identity, the developing party systems, interethnic relations, relations with neighboring states, and the role international organizations (particularly the UN, NATO, and the EU) played in the wars of the Yugoslav succession. Questions for discussion included:

- Why was Romania's 1989 revolution so violent?

- What are the major explanations for the break-up of the Yugoslav federation? What do these explanations tell us about other federal states?

- How stable is the Dayton peace plan likely to be? What does it have in common with other peace settlements after civil wars?

Not surprisingly, the last section raised the most interest since students were eager to talk about events that they had followed throughout the course on CNN and in the newspapers. But most students felt that they were better able to understand contemporary developments-and to critique simplistic explanations of political behavior in the region-by having first focused on the experience of the past. I was pleased to find that many of the students had independently begun to read contemporary accounts of Balkan politics outside the required readings and to come to class with new interpretations gleaned from works by Cohen (1993), Glenny (1992), Owen (1995), Ramet (1996), Thompson (1992), Woodward (1995b), and others. While students came away skeptical about treatments which used "the Ottoman legacy" as an explanatory variable, they nevertheless developed a more nuanced appreciation for the region's complicated past and the ways in which history may (and may not) condition the behavior of political actors today.

\section{Rescuing the Balkans}

This course attempted to place the complex contemporary politics of Southeastern Europe in a wider conceptual and comparative context. The goal was to rescue the Balkans from "instant historians" (Stokes, et al. 1996), a group whose growing oeuvre has often obscured rather than elucidated the sources of political behavior in Europe's southeast. As the course aimed to demonstrate, the region not only represents a fruitful area of research for scholars interested in topics as varied as political culture and ethnic relations, but also provides a fascinating opportunity to involve students in "doing" political science-using ideas and concepts to address pressing real-world problems. The real challenge for instructors is to link the study of Southeastern Europe with broader themes in comparative politics and international relations, while at the same time imparting to students some knowledge of the complex ethnic geography and turbulent history of the region. By so doing, observers may at last cease to attribute recent events to the spectral powers of "Balkan ghosts" (Kaplan 1993) and instead seek to explain Southeastern European politics using the same tools that have been developed in other, more widely studied regions. 


\section{Notes}

1. The author would like to thank an anonymous referee for helpful comments on an earlier version of this article.

\section{References}

Bakic-Hayden, Milica, and Robert M. Hayden. 1992. "Orientalist Variations on the Theme 'Balkans': Symbolic Geography in Recent Yugoslav Cultural Politics." Salvic Review 5l(1): 1-15.

Banac, Ivo. 1984. The National Question in Yugoslavia: Origins, History, Politics. Ithaca: Cornell University Press.

Bringa, Tone. 1995. Being Muslim the Bosnian Way: Identity and Community in a Central Bosnian Village. Princeton: Princeton University Press.

Carnegie Endowment for International Peace. 1993. The Other Balkan Wars. Washington, DC: Carnegie Endowment.

Chirot, Daniel, ed. 1989. The Origins of Backwardness in Eastem Europe. Los Angeles: University of California Press.

Cohen, Lenard J. 1995. Broken Bonds: Yugoslavia's Disintegration and Balkan Politics in Transition. 2nd ed. Boulder, CO: Westview.

Danforth, Loring M. 1995. The Macedonian Conflict. Princeton: Princeton University Press.

Deletant, Dennis. 1995. Ceausescu and the Securitate: Coercion and Dissent in Romania, 1965-1989. London: Hurst.

Friedman, Francine. 1996. The Bosnian Muslims: Denial of a Nation. Boulder, CO: Westview,
Gallagher, Tom. 1995. Romania after Ceausescu. Edinburgh: Edinburgh University Press.

Glenny, Misha. 1996. The Fall of Yugoslavia. 2nd ed. New York: Penguin.

Hall, Brian. 1996. "Rebecca West's War." New Yorker. April 15,74-84.

Hall, Derek. 1994. Albania and the Albanians. New York: Pinter Reference.

Jelavich, Barbara. 1983. History of the Balkans, Vol. 2: Twentieth Century. New York: Cambridge University Press.

Judah, Tim. 1997. The Serbs: History, Myth and the Destruction of Yugoslavia. New Haven: Yale University Press.

Kaplan, Robert D. 1993. Balkan Ghosts. London: Papermac.

Owen, David. 1995. Balkan Odyssey. London: Victor Gollancz.

Poulton, Hugh. 1995. Who Are the Macedonians? London: Hurst.

Ramet, Sabrina Petra. 1996. Balkan Babel: The Disintegration of Yugoslavia from the Death of Tito To Ethnic War. Boulder, CO: Westview.

Rieff, David. 1995. Slaughterhouse: Bosnia and the Failure of the West. New York: Touchstone.

Rothschild, Joseph. 1974. East Central Europe between the Two World Wars. Seattle: University of Washington Press.

Silber, Laura, and Allan Little. 1997. Yugoslavia: Death of a Nation. Rev. ed. New York: Penguin.

Stokes, Gale, John Lampe, and Dennison Rusinow, with Julie Mostov. 1996. "Instant History: Understanding the Wars of the Yugoslav Succession." Slavic Review 55(1): $136-60$.

Tanner, Marcus. 1997. Croatia: A Nation Forged in War. New Haven: Yale University Press.
Thompson, Mark. 1992. A Paper House: The Ending of Yugoslavia. London: Vintage.

Todorova, Maria N. 1997. Imagining the Balkans. New York: Oxford University Press.

Verdery, Katherine. 1991. National Ideology under Socialism: Identity and Cultural Politics in Ceausescu's Romania. Berkeley: University of California Press.

Vickers, Miranda. 1995. The Albanians: $A$ Modern History. London: I. B. Tauris.

West, Rebecca. [1940] 1993. Black Lamb and Grey Falcon: A Journey through Yugoslavia. London: Canongate Classics.

Wolff, Larry. 1994. Inventing Eastern Europe: The Map of Civilization on the Mind of the Enlightenment. Stanford: Stanford University Press.

Wolff, Robert Lee. 1974. The Balkans in Our Time. Cambridge: Harvard University Press.

Woodward, Susan L. 1995a. Balkan Tragedy: Chaos and Dissolution after the Cold War. Washington, DC: Brookings.

Woodward, Susan L. 1995b. Socialist Unemployment: The Political Economy of Yugoslavia, 1945-1990. Princeton: Princeton University Press.

\section{About the Author \\ Charles King is the Ion Ratiu Chair of Ro- manian Studies at Georgetown University. He is co-editor, with Neil Melvin, of Nations Abroad: Diaspora Politics in the Former Soviet Union (Westview, forthcoming), and is the author of numerous articles and book chap- ters on nationalism, the Balkans, Romania, and other subjects.}

\title{
Teaching Democratic Theory Democratically
}

\author{
Mark Mattern, Chapman University
}

Is the classroom appropriately democratized? ${ }^{1}$ To what extent, and in what ways? In this article, I review the results of one experiment in democratic education that may shed some light on these questions. Democratic education is not the same as education for democracy. Education for democracy can be, for example, courses in history and civics which give students basic knowledge requisite for informed participation in a contemporary democracy, but which retain the hierarchical, authoritarian, and elitist elements of traditional, undemocratic teaching. Democratic education, by contrast, entails power sharing within the classroom. Simply asking students their opinions, while a valuable exercise, is not an example of power sharing. Sharing power with students means offering them real choices about course content and process. It requires moving away, partially or wholly, from the hierarchical, authoritarian, and elitist elements that characterize most educational practices today in the United States. Democratic education involves increasing the level of personal responsibility assumed by students and giving the students real decision-making authority without threats of punitive reactions by the instructor.
Why democratize the classroom? First, democratic education better enables the development of democratic skills and dispositions. If students engage routinely in educational practices that teach passivity, deference to elites, acceptance of unaccountable authority and power, and comfort with undemocratic hierarchy, they internalize these traits and accept them as normal. The traditional "banking" model of education, ${ }^{2}$ involving the deposit of knowledge in students by an instructor, teaches these traits of passivity, deference to elites, acceptance of unaccountable authority and power, and 